\title{
Catalytic dehydrative etherification and chlorination of benzyl alcohols in ionic liquids $\dagger$
}

\author{
Hassan A. Kalviri, Chad F. Petten and Francesca M. Kerton* \\ Received (in Cambridge, UK) 19th May 2009, Accepted 29th June 2009 \\ First published as an Advance Article on the web 20th July 2009 \\ DOI: $10.1039 /$ b909866f
}

Dibenzyl ethers and benzyl chloride can be obtained in moderate to excellent yields through Pd-catalysed reactions in hydrophobic ionic liquids using microwave or conventional heating.

Dehydrative reactions can be used for a wide variety of transformations including etherifications, esterifications and thioetherifications. ${ }^{1}$ Generally, this route is more environmentally friendly than classical methods (Williamson and Ullmann) as the only byproduct is water, whereas the use of strongly basic alkoxides or phenoxides with alkyl or aryl halides in the Williamson method produces considerable amounts of salt byproducts. In etherification reactions, a wide variety of catalysts have been employed including alumina, ${ }^{2}$ phase transfer catalysts, ${ }^{3}$ Lewis acids, ${ }^{4}$ and several transition metal complexes. ${ }^{5}$ Among these catalysts, Pd(II) compounds have a special position, ${ }^{6}$ which has led to a recent review in this area. $^{7}$ It should be noted that dehydrative etherification of benzylic alcohols has been investigated to a lesser extent than phenols, however, such catalytic reactions could be useful in synthetic chemistry, e.g. for protecting alcohols. ${ }^{4 c}$

In the area of catalytic dehydration reactions, we thought that the use of hydrophobic ionic liquids (ILs) as reaction media could provide an added benefit to homogeneous catalytic systems by aiding in water abstraction from the reaction mixture. Furthermore, we have employed microwave heating to reduce reaction times and energy consumption. In general, room temperature ILs have attracted great attention during the last decade, since they are non-volatile, non-flammable, potentially recyclable and benign solvents with the ability to dissolve a wide variety of compounds. ${ }^{8}$ In terms of ether synthesis, Ullmann and Williamson methods have been performed using ILs as the reaction media, ${ }^{5 a, 9}$ as well as the promoter. ${ }^{10}$ As far as we are aware, catalytic dehydrative etherification reactions have not been performed in ILs previously.

In our preliminary studies, benzyl alcohol was selected as it is the simplest benzylic alcohol, Table 1. Conventional heating as well as microwave irradiation was used as the energy source. Scheme 1 presents the general reaction conditions and the benzyl alcohol derivatives used in further studies, Table 2. Two hydrophilic and three hydrophobic ILs were used along with several transition metal sources (Table 1, entries 1-15).

Chemistry Department, Memorial University of Newfoundland,

St. John's, Newfoundland, Canada A1B $3 X 7$.

E-mail: fkerton@mun.ca; Fax: +1 709 737-3702;

Tel: $+1709737-8089$

$\dagger$ Electronic supplementary information (ESI) available: Instrumentation and chemicals, EDX analysis and SEM image of the precipitate from some reactions, GC-MS analysis, ${ }^{1} \mathrm{H},{ }^{19} \mathrm{~F}$ and ${ }^{31} \mathrm{P}-\mathrm{NMR}$ data. See DOI: $10.1039 / \mathrm{b} 909866 \mathrm{f}$

1-Butyl-3-methyl imidazolium hexafluorophosphate ([BMIm] $\mathrm{PF}_{6}$ ) gave the highest yields under microwave irradiation in combination with $\mathrm{Pd}\left(\mathrm{CH}_{3} \mathrm{CN}\right)_{2} \mathrm{Cl}_{2}$ (Table 1, entry 1). It should be noted that other environmentally-friendly solvent systems - solvent-free (Table 1, entry 5) and aqueous (Table 1, entry 6)-were not suitable for this reaction. Additionally, reactions in conventional polar, aprotic organic solvents (Table 1, entries 7 and 8) only gave low yields of the desired product. The increased yields obtained in ILs may be due to the unique highly ionic environments afforded by these media that can support ionic intermediates that have been proposed for similar Pd-catalysed reactions in conventional reaction media. ${ }^{6 a}$

As many ether syntheses are $\mathrm{pH}$ dependent, the reactions were examined in the presence of several additives. Under basic conditions (Table 1, entries 16 and 17), no conversion was seen. Conducting the reaction in the presence of acetic acid led to the formation of benzyl acetate, 3 (Table 1, entry 18 ), while benzyl chloride, $\mathbf{2}$, was obtained in excellent yield $(84 \%)$ in the presence of $\mathrm{NH}_{4} \mathrm{Cl}$ (Table 1, entry 19). $\mathrm{NH}_{4} \mathrm{Cl}$ is less hazardous to human health and the environment than other common chlorinating agents including thionyl chloride and concentrated hydrochloric acid. Further studies are ongoing to determine the applicability of this environmentally benign halogenation process. Control reactions have also been performed. In the absence of a transition metal, with and without additives, no conversion of the benzyl alcohol was seen. This indicates that although the hexafluorophosphate anion has a tendency to degrade and can potentially form HF in the reaction mixtures, the reactions are not acid catalysed and the metal, ideally palladium, is an essential component of

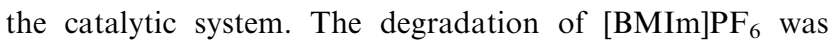
evident through the formation of a precipitate in many of the reactions especially upon prolonged heating. The precipitate contained significant amounts of $\mathrm{Na}$ and $\mathrm{Si}$ which could only have originated from the glass reaction vessels due to their sodium borosilicate content. Furthermore, mild etching of the vessels was seen after some reactions, presumably through in situ action of $\mathrm{HF}$ from $\mathrm{PF}_{6}{ }^{-}$degradation. $\ddagger$

Based on our initial studies, reactions using other benzyl alcohol derivatives (Table 2) and ionic liquids were performed under similar conditions. When 4-methoxy benzyl alcohol was used as the substrate (Table 2, entry 4), the highest yield was obtained. We propose that this is due to the higher stability of the benzylic carbocation formed from this reagent. All other alcohols, with the exception of 4-nitro benzyl alcohol, were successfully coupled and yields of $50-60 \%$ obtained. Furthermore, it should be noted that no precipitate formed during the transformation of 4-methoxy benzyl alcohol. Whereas for 
Table 1 Reactions of benzyl alcohol under different reaction conditions ${ }^{a}$

\begin{tabular}{|c|c|c|c|c|c|c|}
\hline \multirow[b]{2}{*}{ Entry } & \multirow[b]{2}{*}{ Solvent } & \multirow[b]{2}{*}{ Metal source $^{b}$} & \multirow[b]{2}{*}{ Additive } & \multirow[b]{2}{*}{ Yield $^{c}(\%)$} & \multicolumn{2}{|c|}{ Time $(\min ) / \operatorname{Temp}\left({ }^{\circ} \mathrm{C}\right)^{d}$} \\
\hline & & & & & Microwave & Conventional \\
\hline 1 & {$\left[\mathrm{BMIm} \mathrm{PF}_{6}\right.$} & $\mathrm{Pd}\left(\mathrm{CH}_{3} \mathrm{CN}\right)_{2} \mathrm{Cl}_{2}$ & - & $55(\mathbf{1})$ & $7 / 140$ & - \\
\hline 2 & {$\left[\mathrm{BMIm} \mathrm{PF}_{6}\right.$} & $\mathrm{Pd}\left(\mathrm{CH}_{3} \mathrm{CN}\right)_{2} \mathrm{Cl}_{2}$ & - & $23(1)$ & - & $24 \mathrm{~h} / 80$ \\
\hline 3 & {$[\mathrm{BMMIm}] \mathrm{PF}_{6}$} & $\mathrm{Pd}\left(\mathrm{CH}_{3} \mathrm{CN}\right)_{2} \mathrm{Cl}_{2}$ & - & $50(1)$ & $6 / 140$ & - \\
\hline 4 & {$[\mathrm{BMIm}] \mathrm{BF}_{4}$} & $\mathrm{Pd}\left(\mathrm{CH}_{3} \mathrm{CN}\right)_{2} \mathrm{Cl}_{2}$ & - & 0 & $10 / 135$ & - \\
\hline 5 & No solvent & $\mathrm{Pd}\left(\mathrm{CH}_{3} \mathrm{CN}\right)_{2} \mathrm{Cl}_{2}$ & - & 0 & $7 / 90$ & $24 \mathrm{~h} / 90$ \\
\hline 6 & $\mathrm{H}_{2} \mathrm{O}$ & $\mathrm{Pd}\left(\mathrm{CH}_{3} \mathrm{CN}\right)_{2} \mathrm{Cl}_{2}$ & - & Trace (1) & $7 / 90$ & $24 \mathrm{~h} / 90$ \\
\hline 7 & DMSO & $\mathrm{Pd}\left(\mathrm{CH}_{3} \mathrm{CN}\right)_{2} \mathrm{Cl}_{2}$ & - & $5(1)^{g}$ & $9 / 130$ & - \\
\hline 8 & DMF & $\mathrm{Pd}\left(\mathrm{CH}_{3} \mathrm{CN}\right)_{2} \mathrm{Cl}_{2}$ & - & $12(\mathbf{1})^{g}$ & $9 / 130$ & - \\
\hline 9 & {$\left[\mathrm{BMIm} \mathrm{PF}_{6}\right.$} & $\mathrm{Pt}(\mathrm{COD}) \mathrm{Cl}_{2}$ & - & 0 & $7 / 125$ & - \\
\hline 10 & {$[\mathrm{BMIm}] \mathrm{PF}_{6}$} & $\mathrm{RuCl}_{3} \cdot x \mathrm{H}_{2} \mathrm{O}$ & - & $12(\mathbf{1})$ & $7 / 145$ & - \\
\hline 11 & {$\left[\mathrm{BMIm}^{2} \mathrm{PF}_{6}\right.$} & $\mathrm{RuCl}_{3} \cdot x \mathrm{H}_{2} \mathrm{O}$ & - & $23(1)$ & - & $24 \mathrm{~h} / 80$ \\
\hline 12 & {$[\mathrm{BMIm}] \mathrm{BF}_{4}$} & $\mathrm{RuCl}_{3} \cdot x \mathrm{H}_{2} \mathrm{O}$ & - & 0 & - & $24 \mathrm{~h} / 80$ \\
\hline 13 & [BMIm]Cl & $\mathrm{RuCl}_{3} \cdot x \mathrm{H}_{2} \mathrm{O}$ & - & Trace (1) & - & $18 \mathrm{~h} / 80$ \\
\hline 14 & {$[\mathrm{BMIm}] \mathrm{PF}_{6}$} & $\mathrm{FeCl}_{3} \cdot 6 \mathrm{H}_{2} \mathrm{O}$ & - & $24(1)$ & $9 / 130$ & - \\
\hline 15 & {$[\mathrm{BMIm}] \mathrm{PF}_{6}$} & $\mathrm{FeCl}_{3} \cdot 6 \mathrm{H}_{2} \mathrm{O}$ & - & $14(1)$ & - & $4 \mathrm{~h} / 100$ \\
\hline 16 & {$[\mathrm{BMIm}] \mathrm{PF}_{6}$} & $\mathrm{Pd}\left(\mathrm{CH}_{3} \mathrm{CN}\right)_{2} \mathrm{Cl}_{2}$ & $\mathrm{KOH}^{e}$ & 0 & $15 / 158$ & - \\
\hline 17 & {$\left[\mathrm{BMIm}^{2} \mathrm{PF}_{6}\right.$} & $\mathrm{Pd}\left(\mathrm{CH}_{3} \mathrm{CN}\right)_{2} \mathrm{Cl}_{2}$ & $\mathrm{~K}_{2} \mathrm{CO}_{3}{ }^{e}$ & 0 & $15 / 150$ & - \\
\hline 18 & {$\left[\mathrm{BMIm} \mathrm{PF}_{6}\right.$} & $\mathrm{Pd}\left(\mathrm{CH}_{3} \mathrm{CN}\right)_{2} \mathrm{Cl}_{2}$ & $\mathrm{CH}_{3} \mathrm{COOH}^{f}$ & $36(\mathbf{1})$ and $14(3)$ & $10 / 135$ & - \\
\hline 19 & {$[\mathrm{BMIm}] \mathrm{PF}_{6}$} & $\mathrm{Pd}\left(\mathrm{CH}_{3} \mathrm{CN}\right)_{2} \mathrm{Cl}_{2}$ & $\mathrm{NH}_{4} \mathrm{Cl}^{f}$ & $84(2)$ and trace (1) & $10 / 135$ & - \\
\hline 20 & {$[\mathrm{BMIm}] \mathrm{PF}_{6}$} & No catalyst & $\mathrm{NH}_{4} \mathrm{Cl}^{f}$ & 0 & $10 / 95$ & - \\
\hline
\end{tabular}

${ }^{a}$ Typical reaction conditions (for entry 1): IL $0.5408 \mathrm{~g}$, benzyl alcohol $0.0610 \mathrm{~g}, \mathrm{Pd}\left(\mathrm{CH}_{3} \mathrm{CN}\right)_{2} \mathrm{Cl}_{2} 0.0080 \mathrm{~g}$. The homogeneous reaction mixture was sealed with a PTFE cap under a nitrogen blanket. Microwave powers of 150-200 W were used. BMMIm = 1-butyl-2,3-dimethylimidazolium. ${ }^{b} 0.05$ equiv. of Pd with respect to benzylic alcohol. ${ }^{c}$ Yields were calculated relative to benzyl alcohol using ${ }^{1} \mathrm{H}-\mathrm{NMR}$ spectroscopy with acetophenone as the internal standard (for more information see ESI $\dagger$ ). ${ }^{d}$ Time is in minutes unless otherwise mentioned. ${ }^{e} 0.5$ equiv. with respect to benzyl alcohol. ${ }^{f} 1$ equiv. with respect to benzyl alcohol. ${ }^{g} \mathrm{Y}=\mathrm{OMe}$.
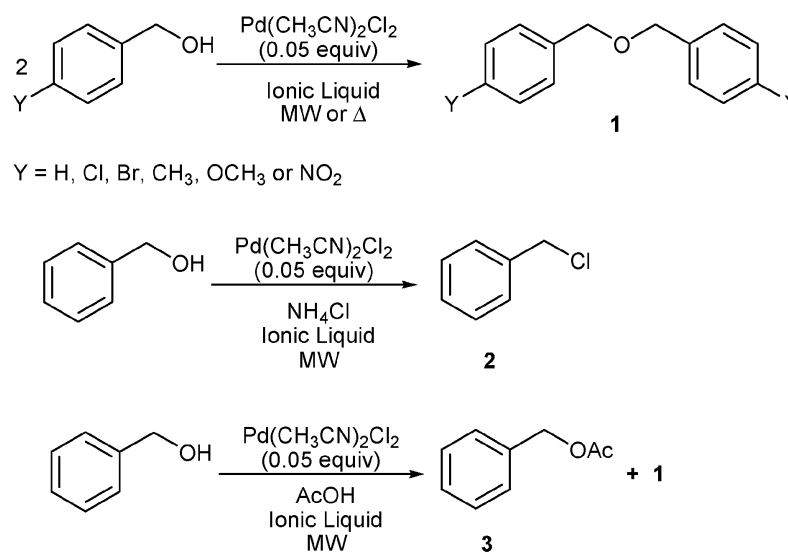

Scheme 1 Pd-catalysed transformations of benzyl alcohols investigated in this study.

other substrates, especially upon prolonged reaction times either thermally or in a microwave, quantities of a catalytically inactive solid were formed (vide supra). Initial recycling studies (Table 2, entries 5 and 6) using the ionic liquid (catalyst phase) from the transformation of 4-methoxy benzyl alcohol (Table 2, entry 4) are promising; yields were maintained or improved when the catalyst/ionic liquid was reused.

Many Pd(II)-catalysed reactions require or are enhanced by the presence of a copper co-catalyst. ${ }^{11}$ Surprisingly, when $\mathrm{CuCl}_{2}$ was used with the $\mathrm{Pd}$ for these reactions, the yield dropped from $57 \%$ to $8 \%$ (Table 2, entries 3 and 10). This information may be useful in determining the nature of the catalytic cycle. Also, [BMMIm] $\mathrm{PF}_{6}(\mathrm{BMMIm}=1$-butyl-2,3dimethylimidazolium) was used to assess whether an $\mathrm{N}$-heterocyclic carbene complex of $\mathrm{Pd}$ was the active species in this

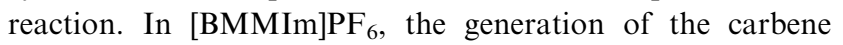

intermediate is impossible. Results using this solvent were similar to $\left[\mathrm{BMIm} \mathrm{PF}_{6}\right.$ (Table 2, entries 1 and 13). Analysis of the reaction mixture by TEM analysis showed no evidence of colloidal Pd. Therefore, we propose that the catalyst is a homogeneous form of Pd.

Since hydrophobic [BMIm] $\mathrm{PF}_{6}$ afforded higher yields than

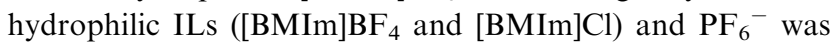
underdoing degradation, an alternative hydrophobic ionic liquid was used. Trihexyl(tetradecyl)phosphonium dodecylbenzene sulfonate $\left(\left[\mathrm{P}_{66614}\right] \mathrm{DBS}\right)$ was employed but did not show a reasonable absorptivity for MW irradiation due to the large size of its cations and anions (Table 2, entry 11); however, under conventional heating, $56 \%$ yield was obtained (Table 2 , entry 9). This is comparable with results obtained using $[\mathrm{BMIm}] \mathrm{PF}_{6}$. Potentially, by doping the $\left[\mathrm{P}_{66614}\right] \mathrm{DBS}$ phase with a strong microwave absorber, the reaction could still be performed using microwave heating.

In attempts to further increase the yield of these reactions, the effects of increased reaction time and temperature were studied for the transformation of 4-methoxy benzyl alcohol in $\left[\mathrm{BMIm}_{\mathrm{PF}}\right.$. When the reaction mixture (Table 2, entry 4) was heated for twenty minutes instead of nine, very little starting material but no ether was seen in the NMR spectrum. However, 4,4'-dimethoxydiphenyl methane (4) was detected as the main product via GC-MS analysis (Fig. S4 and S5, ESI $\dagger)$ \& When the reaction was performed at a higher temperature (7 minutes at $125^{\circ} \mathrm{C}$ ), bis-(4-methoxybenzyl) acetal (5) was detected via GC-MS. As 4 and 5 (Fig. 1) are only seen after prolonged reaction times or at higher temperatures, one can assume that $\mathbf{1}$ is an intermediate in their formation. These products have been observed by other researchers in photochemical and acid-catalysed reactions. ${ }^{12}$ Dehydration products more complex than $\mathbf{1}$ were also observed when we performed 
Table 2 Etherification reactions of para-substituted benzyl alcohol derivatives ${ }^{a}$

\begin{tabular}{|c|c|c|c|c|c|}
\hline Entry & Catalyst & $\mathrm{Y}$ & IL & Yield $(\%)(\mathbf{1})^{b}$ & Time $(\min ) / \operatorname{Temp}\left({ }^{\circ} \mathrm{C}\right)$ \\
\hline 1 & $\mathrm{Pd}\left(\mathrm{CH}_{3} \mathrm{CN}\right)_{2} \mathrm{Cl}_{2}$ & $\mathrm{H}$ & {$\left[\mathrm{BMIm} \mathrm{PF}_{6}\right.$} & 55 & $7 / 140$ \\
\hline 2 & $\mathrm{Pd}\left(\mathrm{CH}_{3} \mathrm{CN}\right)_{2} \mathrm{Cl}_{2}$ & $\mathrm{Cl}$ & {$[\mathrm{BMIm}] \mathrm{PF}_{6}$} & 55 & $10 / 145$ \\
\hline 3 & $\mathrm{Pd}\left(\mathrm{CH}_{3} \mathrm{CN}\right)_{2} \mathrm{Cl}_{2}$ & $\mathrm{CH}_{3}$ & {$\left[\mathrm{BMIm} \mathrm{PF}_{6}\right.$} & 57 & $12 / 114$ \\
\hline 4 & $\mathrm{Pd}\left(\mathrm{CH}_{3} \mathrm{CN}\right)_{2} \mathrm{Cl}_{2}$ & $\mathrm{OCH}_{3}$ & {$[\mathrm{BMIm}] \mathrm{PF}_{6}$} & 71 & $9 / 113$ \\
\hline 5 & Recycle 1 (reuse entry 4) & $\mathrm{OCH}_{3}$ & {$\left[\mathrm{BMIm}^{\mathrm{B}} \mathrm{PF}_{6}\right.$} & 96 & $2 \times 15 / 106$ \\
\hline 6 & Recycle 2 (reuse entry 5) & $\mathrm{OCH}_{3}$ & {$[\mathrm{BMIm}] \mathrm{PF}_{6}$} & 78 & $8 / 116$ \\
\hline 7 & $\mathrm{Pd}\left(\mathrm{CH}_{3} \mathrm{CN}\right)_{2} \mathrm{Cl}_{2}$ & $\mathrm{NO}_{2}$ & {$\left[\mathrm{BMIm} \mathrm{PF}_{6}\right.$} & 0 & $10 / 115$ \\
\hline 8 & $\mathrm{Pd}\left(\mathrm{CH}_{3} \mathrm{CN}\right)_{2} \mathrm{Cl}_{2}$ & $\mathrm{Br}$ & {$[\mathrm{BMIm}] \mathrm{PF}_{6}$} & 6 & $12 / 170$ \\
\hline 9 & Pd cat. precipitate & $\mathrm{Cl}$ & {$[\mathrm{BMIm}] \mathrm{PF}_{6}$} & 8 & $11 / 131$ \\
\hline 10 & $\mathrm{Pd}\left(\mathrm{CH}_{3} \mathrm{CN}\right)_{2} \mathrm{Cl}_{2} / \mathrm{CuCl}_{2} \cdot 2 \mathrm{H}_{2} \mathrm{O}$ & $\mathrm{CH}_{3}$ & {$[\mathrm{BMIm}] \mathrm{PF}_{6}$} & 8 & $10 / 115$ \\
\hline 11 & $\mathrm{Pd}\left(\mathrm{CH}_{3} \mathrm{CN}\right)_{2} \mathrm{Cl}_{2}$ & $\mathrm{OCH}_{3}$ & {$\left[\mathrm{P}_{66614}\right] \mathrm{DBS}$} & 0 & $10 / 58^{c}$ \\
\hline 12 & $\mathrm{Pd}\left(\mathrm{CH}_{3} \mathrm{CN}\right)_{2} \mathrm{Cl}_{2}$ & $\mathrm{OCH}_{3}$ & {$\left[\mathrm{P}_{66614}\right] \mathrm{DBS}$} & 56 & $24 \mathrm{~h} / 90^{d}$ \\
\hline 13 & $\mathrm{Pd}\left(\mathrm{CH}_{3} \mathrm{CN}\right)_{2} \mathrm{Cl}_{2}$ & $\mathrm{H}$ & {$\left[\mathrm{BMMIm} \mathrm{PF}_{6}\right.$} & 50 & $6 / 140$ \\
\hline
\end{tabular}

${ }^{a}$ For reaction conditions, see Table 1 footnote a. ${ }^{b}$ Yields were calculated using ${ }^{1} \mathrm{H}-\mathrm{NMR}$ spectroscopy (for more information see ESI $\dagger$ ). ${ }^{c}$ Using same MW power settings as other reactions. At the highest power setting, 9 minutes were needed to achieve $108{ }^{\circ} \mathrm{C}$ and this temperature could only be held safely for 2 minutes. Yield of (1) and conversion of $\mathrm{BnOH}$ was $0 .{ }^{d}$ Reaction mixture was heated in an oil bath due to lower dielectric heating using $\left[\mathrm{P}_{66614}\right] \mathrm{DBS}$.<smiles>COc1ccc(Cc2ccc(Cc3cc(OC)c(Cc4ccc(OC)cc4)cc3OC)cc2)cc1</smiles>

Fig. 1 Byproducts formed upon prolonged heating of reaction mixtures.

reactions using $\mathrm{PdCl}_{2}$ rather than $\mathrm{Pd}\left(\mathrm{CH}_{3} \mathrm{CN}\right)_{2} \mathrm{Cl}_{2}$. 4 and 6 were observed as the main products (Fig. S6, S7 and S8, ESI $\dagger$ ). $\S$ This demonstrates that acetonitrile is required and probably coordinated to the $\mathrm{Pd}$ in order to give control to the etherification reactions.

In summary, we have shown that $\mathrm{Pd}\left(\mathrm{CH}_{3} \mathrm{CN}\right)_{2} \mathrm{Cl}_{2}$ in a hydrophobic ionic liquid affords a simple catalytic system for the direct condensation of substituted benzyl alcohols to afford their corresponding ethers. In the presence of $\mathrm{NH}_{4} \mathrm{Cl}$, benzyl chloride can be obtained in excellent yield. Although some clues about the mechanism for both reactions have been obtained, e.g. the absence of colloids and $N$-heterocyclic carbene species, the role of the ionic liquid, metal and ligands and the reaction pathway are still under investigation.

We acknowledge support from NSERC of Canada and the Canada Foundation for Innovation in the form of a Discovery Grant, a Research Tools and Instrument Grant, an Undergraduate Summer Research Award (C.F.P.) and a Leaders Opportunity Fund Award (F.M.K.). We would also like to thank Cytec Industries Inc. for samples of $\left[\mathrm{P}_{66614}\right] \mathrm{DBS}$ and Memorial University for funding.

\section{Notes and references}

$\ddagger$ EDX (energy dispersive X-ray) analysis of the precipitate showed the presence of Pd, F, Si, P and Na (Fig. S1, ESI $\dagger$ ). Solid-state ${ }^{19} \mathrm{~F}$ and
${ }^{31} \mathrm{P}-\mathrm{NMR}$ experiments also confirmed the presence of $\mathrm{F}$ and $\mathrm{P}$ (Fig. S2 and S3, ESI $\dagger$ ). Attempts to use the precipitate as a catalyst (as it contained Pd) were made. It was separated, dried and used (Table 2, entry 9), but the yield was low.

$\S \mathbf{4}, \mathbf{5}$ and $\mathbf{6}$ (and their analogues) were not observed by GC-MS upon extracting samples from other reaction mixtures (Tables 1 and 2) and analysing under the same conditions. Furthermore, GC calibration samples of alcohols and ethereal products did not show 4, 5 and 6 . Therefore, it is highly unlikely that $\mathbf{4 , 5}$ and $\mathbf{6}$ were formed within the GC-MS instrument and indeed did form during the microwaveassisted catalytic reactions.

1 K. Manabe, S. Iimura, X.-M. Sun and S. Kobayashi, J. Am. Chem. Soc., 2002, 124, 11971.

2 (a) E. A. Schmittling and J. S. Sawyer, J. Org. Chem., 1993, 58, 3229; (b) J. C. Lee, J. Choi and J. S. Lee, Bull. Korean Chem. Soc., 2004, 25, 1117.

3 (a) G. D. Yadav and O. V. Badure, Ind. Eng. Chem. Res., 2007, 46, 8448; (b) D. H. Hwu, C. Hwang, Y. P. Shih, M. Y. Yeh and C. L. Chao, Ind. Eng. Chem. Res., 1992, 31, 177.

4 (a) V. D. Sarca and K. K. Laali, Green Chem., 2006, 8, 615; (b) A. Corma and M. Renz, Angew. Chem., Int. Ed., 2007, 46, 298; (c) G. V. M. Sharma and A. K. Mahalingam, J. Org. Chem., 1999, 64, 8943.

5 (a) V. V. Namboodiri and R. S. Varma, Tetrahedron Lett., 2002, 43, 4593; (b) J. S. Sawyer, Tetrahedron, 2000, 56, 5045; (c) J. Muzart, Tetrahedron, 2008, 64, 5815.

6 (a) S. Bouquillon, F. Henin and J. Muzart, Organometallics, 2000, 19, 1434; (b) C. A. Parrish and S. L. Buchwald, J. Org. Chem., 2001, 66, 2498; (c) M. C. Willis, D. Taylor and A. T. Gillmore, Chem. Commun., 2003, 2222.

7 J. Muzart, Tetrahedron, 2005, 61, 5955.

8 (a) P. Wasserscheid and T. Welton, Ionic Liquids in Synthesis, VCH, Weinheim, 2007; (b) T. Welton, Coord. Chem. Rev., 2004, 248, 2459; (c) N. V. Plechkova and K. R. Seddon, Chem. Soc. Rev., 2008, 37, 123; (d) F. M. Kerton, Alternative Solvents for Green Chemistry, RSC Publishing, Cambridge, 2009.

9 (a) S. M. S. Chauhan, N. Jain, A. Kumar and K. A. Srinivas, Synth. Commun., 2003, 33, 3607; (b) Y. Luo, J. X. Wu and R. X. Ren, Synlett, 2003, 1734.

10 (a) S. V. More, S. S. Ardhapure, N. H. Naik, S. R. Bhusare, W. N. Jadhav and R. P. Pawar, Synth. Commun., 2005, 35, 3113; (b) F. Mohanazadeh and M. Aghvami, Monatsh. Chem., 2007, 138, 47.

11 For example, X. Zhang and A. Corma, Dalton Trans., 2008, 397.

12 (a) T. Giacco, A. Faltoni and F. Elisei, Phys. Chem. Chem. Phys., 2008, 10, 200; (b) M. Salmón, N. Zavala, A. Cabrera, J. Cárdenas, R. Gaviño, R. Miranda and M. Martínez, J. Mol. Catal. A: Chem., 1995, 104, L127. 